\title{
Public health surveillance for the Toronto 2015 Pan/Parapan American Games
}

\author{
E Chan ${ }^{1 *}$, K Hohenadel $^{1}$, B Lee ${ }^{1}$, M Helferty ${ }^{2}$, JR Harris ${ }^{2}$, L Macdonald ${ }^{1,3}$, T Badiani $^{1}$
}

\section{Abstract}

Background: Public health surveillance for previous Olympic and Paralympic Games have been described in the literature, but surveillance for regional, multisport events on a smaller scale have rarely been explored.

Objective: To describe the public health surveillance planning, implementation, results, and lessons learned from the 2015 Pan/Parapan American Games in Toronto, Ontario, Canada.

Intervention: Public health surveillance planning for the Games began two years in advance and involved local, provincial and federal partners, primarily focusing on infectious disease. From June to August, 2015, enhanced public health surveillance was conducted to support situational awareness and to facilitate the detection of infectious diseases and outbreaks, environmental health hazards and impacts and other major health events.

Outcomes: No major public health incidents occurred that were associated with or a result of hosting the Games. There were two cases of reportable infectious diseases associated with the Games, and 18 public health investigations involving Games-accredited individuals (six related to vaccine-preventable diseases and 12 related to gastrointestinal illnesses or food/water safety violations). Enhanced communication mechanisms, rather than routine and syndromic surveillance systems, were the primary sources of initial notification to surveillance partners on investigations.

Conclusion: Working with its partners, Ontario created a robust public health surveillance system for the 2015 Pan/Parapan American Games. Lessons learned, as well as the relationships and capacity developed through this experience, will be applied towards public health surveillance planning for future events.

Suggested citation: Chan E, Hohenadel K, Lee B, Helferty M, Harris JR, Macdonald L, Badiani T. Public health surveillance for the Toronto 2015 Pan/Parapan American Games. Can Commun Dis Rep. 2017;43(7/8):156-63. https://doi.org/10.14745/ccdr.v43i78a04

\section{Introduction}

In July and August 2015, Toronto and 15 neighbouring municipalities in Ontario, Canada hosted the Toronto 2015 Pan/Parapan American Games (referred to collectively as "the Games"), a regional multisport event involving approximately 10,000 athletes and officials representing 41 countries from the Americas. The combined event involved more athletes and competitions than any multisport event ever held in Canada, including the Vancouver 2010 Olympics and Paralympics. During the 2015 Games, which ran from July 10 to 26 for the Pan American Games and August 7 to 15 for the Parapan American Games, about 250,000 spectators and 20,000 volunteers participated in the sporting and associated cultural events $(1,2)$.

Like other international multisport events, the Games are a type of planned mass gathering (3). The goals of the health-related planning for the Games were to mitigate their impact on the Ontario health care system and to protect the health of residents, event participants and visitors. This was a complex effort given the expansive geographic footprint of the Games across southern Ontario. One aspect of this process was public health surveillance planning, which required close collaboration between 15 surveillance partner organizations including the Toronto 2015 Pan/Parapan American Games Organizing Committee (TO2015), the Public Health Agency of Canada, provincial government agencies and ministries, a local public

\section{Affiliations}

${ }^{1}$ Public Health Ontario, Toronto, ON

2 Population and Public Health Division, Ministry of Health and Long-Term Care, Toronto, ON

${ }^{3}$ Dalla Lana School of Public Health, University of Toronto, Toronto, ON

*Correspondence: ellen.chan@ oahpp.ca health informatics team, 10 local public health units and public health laboratories.

Many previous international multisport events have also involved significant advanced health planning. Potential public health-specific hazards that have been previously identified include trauma, injury and substance misuse; extreme weather events; chemical, radiological, biological and nuclear threats; and infectious diseases such as food- and waterborne disease, sexually transmitted infections and respiratory infections (4-6).

Despite a lack of clear evidence that international multisport events increase the risk of transmission of infectious diseases $(4,7)$, these events may increase opportunities for disease transmission because:

- infectious diseases can be imported from visitors' countries of origin;

- $\quad$ susceptible visitors may be exposed to infectious diseases endemic to the host country;

- living arrangements are communal and events can be crowded;

- new, mobile or temporary food vendors and sanitation facilities are brought in; and

- the strain on the health care system may cause delayed responses (5,7-9). 
During international multisport events, public health surveillance is intended to identify and quantify - or to reassure in the absence of-public health threats to allow for timely action, if necessary $(5,8,10)$. Enhanced public health surveillance planning and response is not required for all mass gatherings; its usefulness depends on a number of factors: the type of event, geographic area, duration and number of international visitors. The need for enhanced surveillance is also influenced by the nature and comprehensiveness of the existing routine public health surveillance system (10).

Enhanced public health surveillance systems have been described for several previous Olympic Games (11-14); however, smaller-scale, regional, multisport events such as the Pan/Parapan American Games have rarely been explored.

This article describes the Toronto 2015 Pan/Parapan American Games public health surveillance planning, implementation, results, and lessons learned in order to help inform future planning for similar mass gathering events.

\section{Intervention}

The primary purpose of public health surveillance for the Pan/Parapan American Games was to support ongoing situational awareness leading up to, during, and immediately following the Games, facilitating the ability to quickly detect sporadic infectious disease activity, outbreak activity, environmental health hazards and impacts, and major health events.

\section{Advance planning}

From November 2013 to December 2014, an advance planning group of public health surveillance experts from multiple jurisdictions developed public health surveillance recommendations in Ontario using a consensus approach. The planning group was primarily focused on infectious disease; a separate group was responsible for ensuring food and water safety related to the Games. The group's work involved determining surveillance objectives for each phase (i.e., before/ during/after the Games), identifying potential public health threats based on a review of literature and results from a Hazard Identification and Risk Assessment process; reviewing available sources of data and information; and identifying gaps in available sources. Sources were recommended based on an assessment of the threats to be monitored, population covered, timeliness, availability, status (i.e. whether established or needing development) and usage (pre, during or post event). Overarching themes considered in making the recommendations included how the information would meet surveillance objectives and inform public health action. The completed recommendations included strengthening reporting and analysis of established sources; adopting and using additional sources at local levels where available; and acquiring or developing new sources (Table 1).

\section{Operational planning}

A separate working group composed mainly of local and provincial epidemiologists implemented the recommendations. From December 2014 to June 2015, members collaborated to develop processes, schedules, templates and other reference documents for use when conducting surveillance for the Games. Concurrently, each surveillance partner also developed complementary surveillance plans and analyses for their
Table 1: Overview of data and information sources used to monitor public health threats at the provincial level ${ }^{1}$ for the Toronto 2015 Pan/Parapan American Games (June 17-August 27, 2015)

\begin{tabular}{|c|c|c|}
\hline $\begin{array}{c}\text { Surveillance } \\
\text { type }\end{array}$ & $\begin{array}{l}\text { Data or information } \\
\text { source (surveillance } \\
\text { partners responsible) }\end{array}$ & $\begin{array}{c}\text { Games-specific/ } \\
\text { Enhanced/Routine } \\
\text { surveillance } \\
\text { activities }\end{array}$ \\
\hline \multirow[t]{2}{*}{$\begin{array}{l}\text { Event } \\
\text { surveillance }\end{array}$} & $\begin{array}{l}\text { Public health coordinator } \\
\text { (provincial/Games): A public } \\
\text { health professional who was } \\
\text { embedded in the polyclinic in } \\
\text { the athletes' village }\end{array}$ & $\begin{array}{l}\text { Games-specific: The } \\
\text { coordinator worked with } \\
\text { the TO2015 medical } \\
\text { team to gather and share } \\
\text { information and provide } \\
\text { support for public } \\
\text { health-related issues }\end{array}$ \\
\hline & $\begin{array}{l}\text { Surveillance teleconferences } \\
\text { (all partners): Held on those } \\
\text { days that public health } \\
\text { surveillance reports for P/PAG } \\
\text { were produced }\end{array}$ & $\begin{array}{l}\text { Games-specific: Calls } \\
\text { were used to share } \\
\text { and assess situations of } \\
\text { potential public health } \\
\text { concern, and to help } \\
\text { decide which situations } \\
\text { would be listed as report } \\
\text { highlights }\end{array}$ \\
\hline \multirow[t]{2}{*}{$\begin{array}{l}\text { Reportable } \\
\text { infectious } \\
\text { diseases }\end{array}$} & \multirow[t]{2}{*}{$\begin{array}{l}\text { iPHIS (provincial): Ontario's } \\
\text { infectious disease surveillance } \\
\text { and reporting system }\end{array}$} & $\begin{array}{l}\text { Routine: Ran daily } \\
\text { aberration-detection } \\
\text { algorithms on select } \\
\text { diseases }\end{array}$ \\
\hline & & $\begin{array}{l}\text { Enhanced: Automated } \\
\text { production of case } \\
\text { counts of reportable } \\
\text { diseases by week } \\
\text { compared to historical } \\
\text { averages; search } \\
\text { for P/PAG-related } \\
\text { exposures reported in a } \\
\text { standardized format in } \\
\text { accordance with a } \\
\text { Games-specific } \\
\text { enhanced surveillance } \\
\text { directive }\end{array}$ \\
\hline Laboratory & $\begin{array}{l}\text { PHOL (provincial): Repository } \\
\text { of all submissions to Public } \\
\text { Health Ontario for laboratory } \\
\text { testing and confirmation } \\
\text { (excludes testing by hospitals } \\
\text { and community laboratories) }\end{array}$ & $\begin{array}{l}\text { Enhanced: Summarized } \\
\text { notifications and } \\
\text { submissions of } \\
\text { Games-related } \\
\text { specimens to PHOL for } \\
\text { testing }\end{array}$ \\
\hline \multirow[t]{2}{*}{ Syndromic } & $\begin{array}{l}\text { Gold Medal System } \\
\text { (provincial/Games): System } \\
\text { included records of medical } \\
\text { encounters with accredited } \\
\text { individuals (including athletes, } \\
\text { coaches, and officials) when } \\
\text { they accessed medical } \\
\text { services provided by TO2015 }\end{array}$ & $\begin{array}{l}\text { Games-specific: TO2015 } \\
\text { provided aggregate } \\
\text { counts for provincial } \\
\text { analysis of illness- and } \\
\text { infection-related } \\
\text { (determined by clinical } \\
\text { assessment) medical } \\
\text { encounters by day and } \\
\text { overall, reporting on } \\
\text { increases beyond two } \\
\text { standard deviations } \\
\text { above a three-day } \\
\text { moving average }\end{array}$ \\
\hline & $\begin{array}{l}\text { Telehealth Ontario } \\
\text { (provincial): A free, } \\
\text { confidential telephone } \\
\text { service for Ontario's general } \\
\text { public to seek health advice } \\
\text { or information }\end{array}$ & $\begin{array}{l}\text { Games-specific: } \\
\text { Categorized calls across } \\
\text { the province into five } \\
\text { syndromes }{ }^{2} \text { during the } \\
\text { Games and completed } \\
\text { statistical analyses on } \\
\text { these syndromes for } \\
\text { potential geographic } \\
\text { clusters that were } \\
\text { greater than the } \\
\text { expected number of } \\
\text { calls for the time period } \\
\text { and geographic area in } \\
\text { question, using a } \\
\text { three-year historical }\end{array}$ \\
\hline
\end{tabular}




\begin{tabular}{|c|c|c|}
\hline $\begin{array}{c}\text { Surveillance } \\
\text { type }\end{array}$ & $\begin{array}{l}\text { Data or information } \\
\text { source (surveillance } \\
\text { partners responsible) }\end{array}$ & $\begin{array}{c}\text { Games-specific/ } \\
\text { Enhanced/Routine } \\
\text { surveillance } \\
\text { activities }\end{array}$ \\
\hline \multirow[t]{2}{*}{$\begin{array}{l}\text { Syndromic } \\
\text { (con't) }\end{array}$} & & $\begin{array}{l}\text { baseline; the number of } \\
\text { callers with attendance } \\
\text { at P/PAG events } \\
\text { was available; also } \\
\text { assessed call volume by } \\
\text { syndrome }\end{array}$ \\
\hline & $\begin{array}{l}\text { ACES (local/provincial } \\
\text { analysis by ACES team): } \\
\text { System captures data on } \\
\text { chief complaints from } \\
\text { emergency department visits } \\
\text { and all hospital admissions, } \\
\text { covering } 53 \text { reporting } \\
\text { hospitals across } 10 \text { local } \\
\text { public health units in the } \\
\text { Games geographical area } \\
\text { (15) }\end{array}$ & $\begin{array}{l}\text { Enhanced: Real-time } \\
\text { analysis of } 15 \\
\text { predefined syndromes } \\
\text { of interest (e.g. } \\
\text { heat-related } \\
\text { illness, asthma and } \\
\text { gastrointestinal issues). } \\
\text { System-generated } \\
\text { alerts or deviations } \\
\text { over expected seasonal } \\
\text { baseline levels were } \\
\text { reported }\end{array}$ \\
\hline Situational & $\begin{array}{l}\text { PHIMS (local/provincial } \\
\text { analysis by the ACES team): } \\
\text { Online platform displays } \\
\text { real-time environmental } \\
\text { data (e.g. air quality } \\
\text { markers, storm events and } \\
\text { temperature stress) along } \\
\text { with ACES, demographic, } \\
\text { and social deprivation indices } \\
\text { on a geographical interface } \\
\text { (16) }\end{array}$ & $\begin{array}{l}\text { Enhanced: PHIMS } \\
\text { platform data streams } \\
\text { were monitored in } \\
\text { the event that at-risk } \\
\text { populations might } \\
\text { need to be informed } \\
\text { or evacuated due to } \\
\text { a weather-related } \\
\text { emergency or potential } \\
\text { terrorist threat }\end{array}$ \\
\hline International & $\begin{array}{l}\text { GPHIN (provincial/federal): } \\
\text { Program that uses an } \\
\text { automated web-based } \\
\text { system to scan newspapers } \\
\text { and other communications } \\
\text { worldwide for potential } \\
\text { indicators of outbreaks. } \\
\text { These are then analyzed } \\
\text { and rapidly assessed by a } \\
\text { multilingual, multidisciplinary } \\
\text { team (17) }\end{array}$ & $\begin{array}{l}\text { Enhanced: Assessed } \\
\text { identified events for } \\
\text { their potential risk and } \\
\text { impact on the Games, } \\
\text { with the most relevant } \\
\text { or concerning events } \\
\text { included in provincial } \\
\text { surveillance report } \\
\text { following subjective } \\
\text { expert review }\end{array}$ \\
\hline
\end{tabular}

Abbreviations: ACES, Acute Care Enhanced Surveillance System; GPHIN, Global Public Health Intelligence Network; iPHIS, integrated Public Health Information System; P/PAG, Pan/Parapan American Games; PHIMS, Public Health Information Management System; PHOL, Public Health Ontario Laboratory; TO2015, Toronto 2015 Pan/Parapan American Games Organizing Committee 1 Other recommended data and information sources used by public health units for their local surveillance during the Games are not listed in this table

2 Telehealth Ontario calls were categorized into five syndromes of interest for P/PAG surveillance: fever/influenza-like illness, gastrointestinal syndrome, heat syndrome, rash syndrome and respiratory syndrome

organization, with the opportunity for sharing ideas through the working group. In spring 2015, the group completed three practice runs of the Games surveillance cycle and applied the lessons learned to finalizing the processes and materials.

\section{Public health coordinator}

In line with the surveillance recommendations, a Public Health Coordinator acted as a key link between TO2015 and the public health system. Before the Games, the coordinator met regularly with the TO2015 medical team to establish a strong relationship and to understand the processes and infrastructure associated with the Games. During the Games, the coordinator was embedded in the TO2015 medical team working from the polyclinic (a large multidisciplinary clinic) in the main athletes' village. The coordinator developed courses and arranged training on onsite infectious disease reporting and preventive measures; coordinated disease reporting, laboratory communications and requests for scientific/technical advice; participated in outbreak investigations; and extracted TO2015 clinic data for syndromic surveillance.

\section{Surveillance cycle}

The working group set the surveillance period for the Games to run from June 17 to August 27, 2015, that is, starting from approximately two weeks before the competitions began until approximately two weeks after the last one. As part of operational planning, the working group developed a schedule of 38 reporting dates within this surveillance period for holding surveillance teleconferences and producing the surveillance report. During the competitions, reporting took place Monday through Friday; whereas reporting was less frequent in the periods before and after competition days, as well as during the break between the Pan/Parapan American Games. The process, activities, responsibilities and timelines for the Games surveillance cycle on a reporting day are outlined in Figure 1.

\section{Figure 1: Daily public health surveillance cycle for the Toronto 2015 Pan/Parapan American Games (June 17-August 27, 2015)}

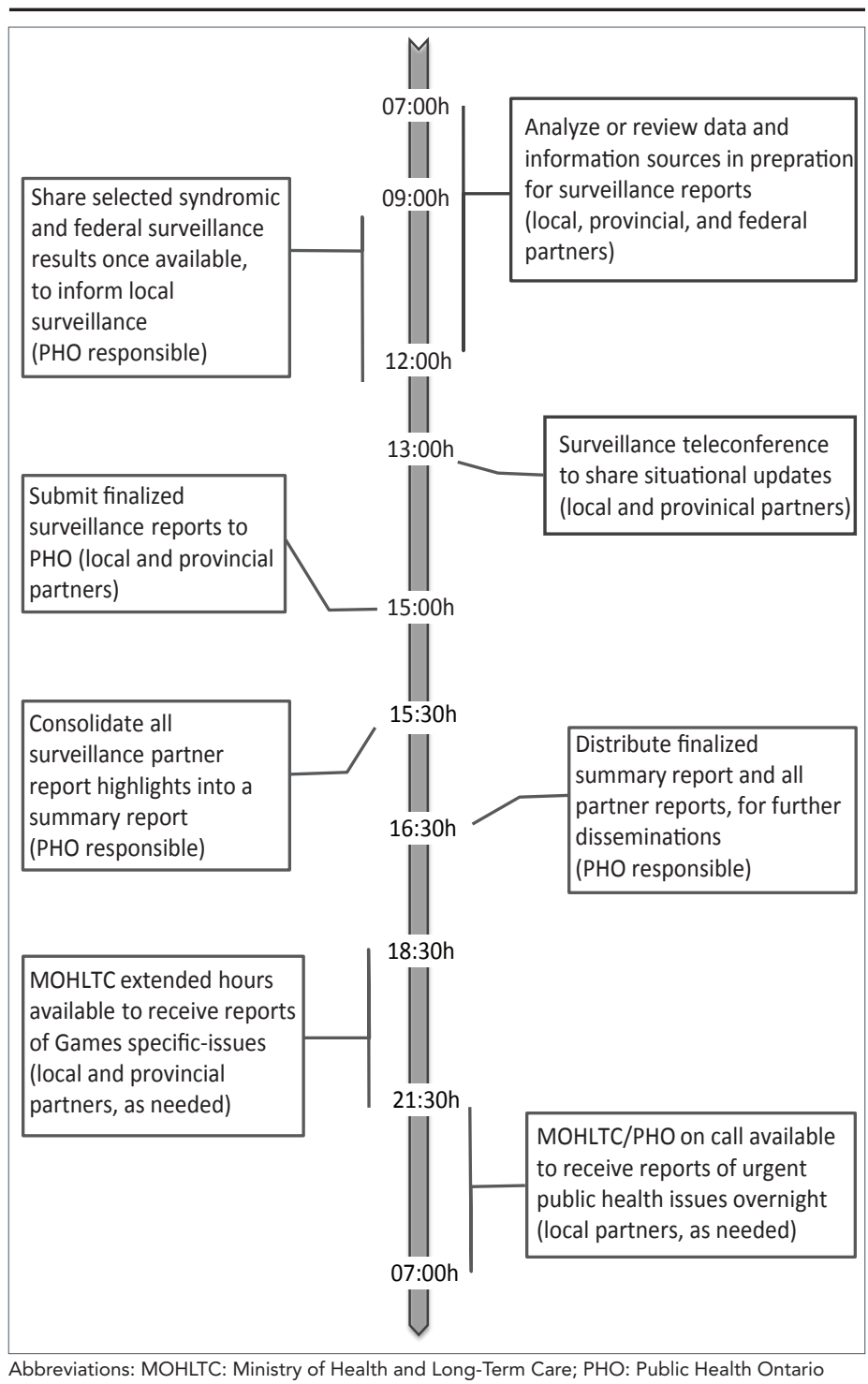


The advanced planning group identified nine data and information sources that met the criteria for Games surveillance at the provincial level (Table 1). For each of the 38 reporting days, Public Health Ontario (an arms-length agency of the Ontario government) produced or distributed reports based on analyses of these sources. Generally, any increases above baseline or clusters/aberrations detected through statistical analysis were included in surveillance reports. Depending on when events were scheduled in their jurisdiction, each of the 10 public health units in the Games footprint produced reports based on surveillance data and information sources available at the local level (e.g. complaint hotlines, food establishment closures, water safety issues, weather alerts) and participated in surveillance teleconferences for a subset of these dates. All other surveillance partners participated throughout the entire surveillance period. The surveillance teleconferences that took place at 1 p.m. (13:00 hours) provided an opportunity for partners to share and assess situations of potential public health concern. A series of questions developed during operational planning (Text box) were used by partners as guiding principles to help determine which situations to include as highlights for their respective surveillance reports and for further dissemination. No rating scale or additional instructions were provided in applying the questions; surveillance partners were free to use the questions in any way that would be helpful for their assessment.

Criteria considered in selecting situations to highlight in surveillance reports for the 2015 Pan/Parapan Games

- Does the issue impact the Games or have the potential to impact the Games?

- Is the issue of public health significance (regardless of whether it is Games related)?

- Does the issue have the potential to have a high public health impact (e.g., pathogen with high potential to cause an epidemic)?

- Is the issue high profile (i.e., is receiving or has the potential to receive media attention)?

- Would other surveillance partners who receive the report benefit from being informed of the issue for their situational awareness?

- Will there be public health action as a result of the issue?

- Is the event usual or unexpected?

- Is there a significant risk of international spread?

After receiving surveillance partner reports, Public Health Ontario compiled local, provincial and national highlights into a summary report. The report was emailed, along with other surveillance reports, back to surveillance partners and was also sent to the Ontario Ministry of Health and Long-Term Care's Emergency Operations Centre for further dissemination.

Outside of this regular schedule, the Ministry Emergency Operations Centre and supporting on-call structures (Figure 1) provided after-hours support throughout the Games surveillance period so that partners could report any immediate, urgent public health incidents.

\section{Disseminating surveillance findings}

The Ministry Emergency Operations Centre was active throughout the surveillance period, coordinating situational awareness and response to the Games, including a daily health system communications cycle. This cycle included regularly scheduled calls with a variety of health system partners and culminated in daily situation reports that summarized each day's health system status, risks and actions.

Highlights of the summary surveillance reports were included in the daily situation reports. These situation reports were then shared across the Ontario health system within the geographical areas involved with the Games, including public health units, paramedic and ambulance services, hospitals and primary care. The reports were also disseminated to TO2015 and other non-health planning partners such as the central Provincial Emergency Operations Centre, which coordinates the Ontario government's overall response.

\section{Outcomes}

There were no major public health incidents associated with or as a result of hosting the Games. Surveillance partners highlighted 18 local public health investigations. Surveillance partners were initially notified of these investigations through the Public Health Coordinator, surveillance teleconferences and/ or the extended hours and on-call processes (Figure 2); only two investigations involved confirmed cases of reportable infectious diseases: an athlete's case of chickenpox and a spectator's case of campylobacteriosis. Twelve of the investigations involved Games-accredited individuals (i.e. athletes, coaches and officials), including six investigations related to vaccine-preventable diseases and 12 related to gastrointestinal illnesses or food/ water safety violations (three of these investigations are described in Appendix 1).

\section{Figure 2: Highlighted public health investigations during the Toronto 2015 Pan/Parapan American Games public health surveillance period (June 17-August 27, 2015)}

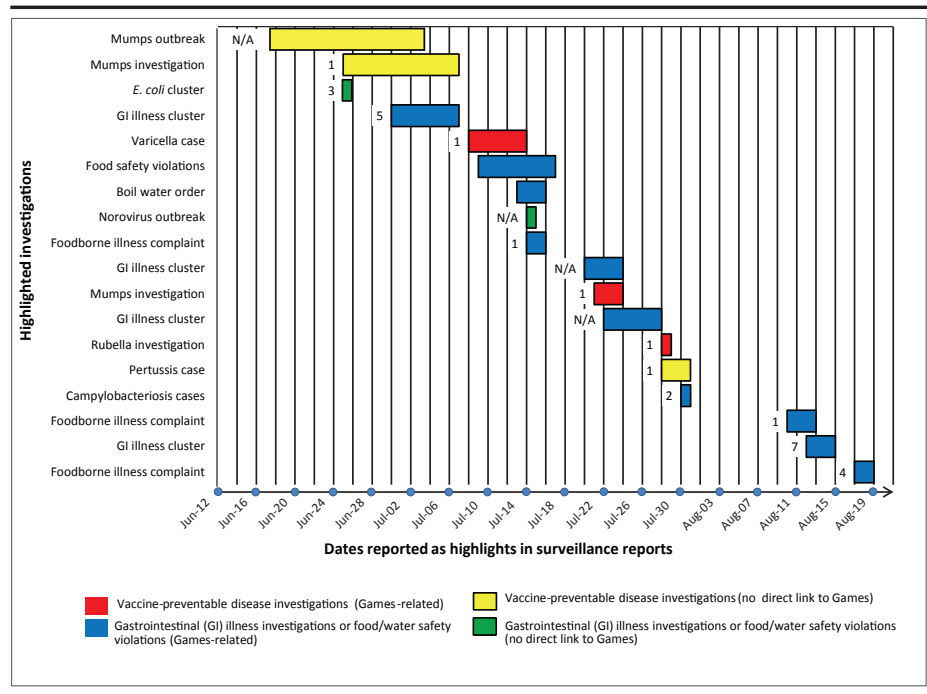

Abbreviations: $\mathrm{Gl}$, gastrointestinal; $\mathrm{N} / \mathrm{A}$, information on number of cases under investigation was unclear and/or not included in surveillance reports

Legend: Numbers to the left of the bars represent the number of people under investigation for each situation. A blank space indicates that the investigation was related to food safety but no related cases were identified

The results of provincial-level surveillance activities by data and information source are summarized in Table 2. Syndromic surveillance systems did not identify any trends, clusters or other alerts that initiated or corresponded with any of the investigations reported by public health units. Although exposures and confirmed cases were reported through the reportable infectious disease information system, data entry 
occurred after the information had already been shared through the Games surveillance reporting process. In general, provincial-level surveillance was largely supportive in nature and provided situational awareness.

Table 2: Results of provincial public health surveillance for the Toronto 2015 Pan/Parapan American Games (June 17-August 27, 2015)

\begin{tabular}{|c|c|}
\hline $\begin{array}{l}\text { Data/information } \\
\text { source(s) }\end{array}$ & Surveillance results \\
\hline $\begin{array}{l}\text { Public health } \\
\text { coordinator }\end{array}$ & $\begin{array}{l}\text { Two individuals shared the role of providing } \\
\text { rotating support over } 44 \text { days in the Athletes' } \\
\text { Village } \\
\text { Sixteen requests for public health support } \\
\text { received }\end{array}$ \\
\hline $\begin{array}{l}\text { Surveillance } \\
\text { teleconferences }\end{array}$ & $\begin{array}{l}\text { A total of } 38 \text { surveillance teleconferences } \\
\text { held with participation from up to } 14 \text { partner } \\
\text { organizations, corresponding with each } \\
\text { surveillance report production day }\end{array}$ \\
\hline iPHIS & $\begin{array}{l}\text { Four Games-related exposures reported } \\
\text { in association with reportable disease } \\
\text { investigations, resulting in two confirmed } \\
\text { cases: a chickenpox case in a P/PAG athlete } \\
\text { and a campylobacteriosis case in a spectator } \\
\text { with foodborne exposure from an unknown } \\
\text { food vendor }\end{array}$ \\
\hline \multirow[t]{2}{*}{ PHOL } & $\begin{array}{l}\text { Five notifications on incoming specimens to } \\
\text { the P/PAG response phone number }\end{array}$ \\
\hline & $\begin{array}{l}\text { Nine Games-related specimens received for } \\
\text { laboratory testing }\end{array}$ \\
\hline \multirow[t]{2}{*}{ Gold Medal System ${ }^{1}$} & $\begin{array}{l}\text { A total of 7,677 medical encounters were } \\
\text { reported based on medical services provided } \\
\text { by TO2015 to P/PAG-accredited individuals. } \\
\text { Of these, 1,940 were illness-related (of these, } \\
376 \text { were infection-related) }\end{array}$ \\
\hline & $\begin{array}{l}\text { A total of } 197 \text { of infection-related medical } \\
\text { encounters affected the respiratory system }\end{array}$ \\
\hline \multirow[t]{3}{*}{ Telehealth Ontario } & $\begin{array}{l}\text { A total of } 75,547 \text { calls from across Ontario } \\
\text { during the surveillance period, with volumes } \\
\text { highest for gastrointestinal syndrome }(5,283 \\
\text { calls) and respiratory syndrome }(4,195 \text { calls })\end{array}$ \\
\hline & $\begin{array}{l}\text { A total of } 130 \text { temporal-spatial clusters } \\
\text { of public health interest detected across } \\
\text { Ontario; the most common clusters of interest } \\
\text { were for respiratory syndrome ( } 46 \text { clusters), } \\
\text { followed by rash syndrome ( } 34 \text { clusters) and } \\
\text { gastrointestinal syndrome ( } 29 \text { clusters) }\end{array}$ \\
\hline & $\begin{array}{l}\text { Eight callers from the detected clusters } \\
\text { reported attending a P/PAG-related event }\end{array}$ \\
\hline ACES and PHIMS & $\begin{array}{l}\text { A total of } 19 \text { ACES syndromes and numerous } \\
\text { PHIMS environmental indicators were } \\
\text { monitored }\end{array}$ \\
\hline GPHIN & $\begin{array}{l}\text { A total of } 237 \text { events worldwide assessed } \\
\text { with potential risk and impact to Games; } 52 \\
\text { of these events further assessed as possibly } \\
\text { having impact on the Games }\end{array}$ \\
\hline
\end{tabular}

Abbreviations: ACES, Acute Care Enhanced Surveillance System; GPHIN, Global Public Health Intelligence Network; iPHIS, integrated Public Health Information System; P/PAG, Pan/Parapan American Games; PHIMS, Public Health Information Management System; PHOL, Public Health Ontario Laboratory; TO2015, Toronto 2015 Pan/Parapan American Games Organizing Committee ${ }^{1}$ TO2015 medical clinic services were only provided on July 1-29 and August 2-18, 2015

\section{Discussion}

Public health surveillance during the 2015 Pan/Parapan American Games in Toronto identified no major public health incidents that were associated with, or as a result of, hosting the Games. The lack of major incidents was not surprising given similar experiences from previous summer Olympic and Paralympic Games (11-14), Canada's well-established public health infrastructure, results from the Hazard Identification Risk Assessment, and the profile of visitors to the Pan/Parapan Games (18).

\section{Performance of surveillance system}

Syndromic surveillance systems are intended to provide rapid yet unspecific data as a complement to traditional surveillance systems, to enable early identification and intervention for potential public health threats (19). The provincial-level syndromic surveillance data sources used during the Games did not produce the initial notifications or alerts that triggered the highlighted public health investigations; nor were these alerts corroborated by the other data and information sources used for Games surveillance. Although alerting thresholds were developed as part of the planning process for the Games, limited prior experience in using these data sources and/or applying them for syndromic surveillance meant that these criteria were largely based on subjective expert input, and their usefulness had not been previously validated. When preparing new syndromic surveillance data sources or methods for future mass gathering events, sufficient time for training, practice and gathering of baseline data and trends should be allowed.

On the other hand, surveillance partners have had extensive experience with Ontario's routinely used reportable infectious disease information system, where reported cases must meet routine provincial case definitions. However, the time required to meet these criteria meant that initial notification of infectious disease case investigations during the Games arose through other sources. From our experience, a reportable disease surveillance system serves best as a historical record for details on Games-associated reportable disease cases and to understand baseline incidence.

The enhanced communication mechanisms (including the Public Health Coordinator, surveillance teleconferences, and extended hours/on-call process) implemented for Games were the primary sources of initial notification to surveillance partners on new investigations. Developing relationships, and new or enhanced communication mechanisms during planning phases, proved to be the most effective methods for providing timely and relevant updates to inform public health action. This experience further supports the importance of having processes and people in place to rapidly communicate potential public health threats and support public health action, a point often made in mass gatherings surveillance literature $(7,10,13)$.

\section{Lessons learned}

The local public health units across the Games footprint had various levels of involvement with the Games, which led to planning challenges in balancing flexibility and consistency. Although efforts were made to accommodate variations in local systems, some public health units requested further provincial guidance and a standard surveillance report template. Another challenge was balancing a comprehensive approach with sustainability of activities. Planning and implementing the 
surveillance cycle throughout the Games had significant resource implications for all surveillance partners, with the commitment being particularly burdensome for public health units with few events.

The planning structure for the Games involved a separate planning process for food and water safety. Public health units and other health system partners were unsure of the appropriate forum for reporting food handling and water safety issues at venues, especially in the absence of any reported illness. As a result, such issues were inconsistently reported through various channels. The relationship between surveillance and other reporting structures could have benefited from more clarity and integration. During a mass gathering, an environmental health surveillance system that is integrated with the rest of the public health surveillance cycle could better facilitate timely public health interventions (20).

Over the course of the Games surveillance cycle, reaction to the disseminated public health surveillance information highlighted a knowledge gap between health partners and non-health partners (e.g. Games organizers; fire, police and intelligence services; other government ministries involved with the events such as transportation). Non-health partners who received surveillance reports often did not know what types of infectious diseases can be expected during the summer in Ontario; they occasionally needed to be reassured that the situations being reported were manageable through routine follow-up. In future, public health partners who disseminate surveillance information should be diligent in providing the necessary context and interpretation in reports and other pre-Games communications to help non-health partners understand the appropriate level of response for the reported situations.

\section{Conclusion}

Public health surveillance for the Toronto 2015 Pan/Parapan American Games provided situational awareness and reassured organizers, government partners and the media, thus fulfilling an important role. In carrying out these activities, we have learned that Ontario can provide efficient and sustainable support to future mass gathering events. Support for future events should involve continuing with Ontario's well-developed routine surveillance activities as well as ensuring that enhanced communication mechanisms are in place. Particular attention must be paid to integrating food and water safety into the communication channels and ensuring that non-health partners understand the context and implications of the updates presented. Moving forward, staff from all surveillance partner organizations can apply the relationships and capacity gained through their involvement with the Games to more efficiently support mass gathering events across the province, large and small. As technologies advance, new and evolving surveillance methods and sources such as crowd-sourced or participatory surveillance initiatives may be used for future events.

\section{Authors' statements}

$\mathrm{BL}, \mathrm{TB}, \mathrm{MH}, \mathrm{JRH}$ - advance planning group members (methodology)

$\mathrm{EC}, \mathrm{KH}, \mathrm{BL}, \mathrm{TB}, \mathrm{MH}, \mathrm{JRH}$ - operational planning and implementation of public health surveillance for the Games (methodology)

\section{Authors' statements (continued)}

$B L, E C$ - software, validation, formal analysis

$\mathrm{EC}, \mathrm{KH}$ - data collection and curation, investigation

$\mathrm{BL}, \mathrm{EC}, \mathrm{KH}$ - visualization

$\mathrm{EC}, \mathrm{KH}, \mathrm{BL}, \mathrm{TB}, \mathrm{MH}, \mathrm{JRH}$ - writing-original draft

All authors - conceptualization, writing-review/editing

\section{Conflict of interest}

None.

\section{Acknowledgements}

We thank the following groups and individuals for their work in developing and carrying out the surveillance strategy for the Pan/Parapan Am Games: Surveillance Working Group; Surveillance Operationalization Working Group; Toronto 2015 medical team; at Public Health Ontario: Vicky Springmann, Ryan Walton, Morgan Barnes, Surveillance Services team, Communicable Diseases, Emergency Preparedness and Response department, Public Health Ontario Laboratory; at the Ministry of Health and Long-Term Care: Sarah Levitt and Marcilyn Cianfarani.

We would like to thank Dr Brian Schwartz for his review of this article, and Adam van Djik, Alex Marchand-Austin, Andrea Van Der Voort, Carole Craig, Gregory Kujbida, Dr Jessica Hopkins, Lise Trotz-Williams, Monali Varia, Philip Abdelmalik, Ruth Diaz-Chambers, Scott Cholewa, Shanna Hoetmer and Tony Camara for reviewing sections of this paper.

\section{Funding}

This work was supported by Public Health Ontario and the Ontario Ministry of Health and Long-Term Care as part of operational activities.

\section{References}

1. Toronto 2015 Pan Am / Parapan Am Games. Largest ever Parapan Am games make history [Internet]. Toronto Star. (Toronto Ed.) 2015 Aug 15 [cited 2016 Jul 05]. Available from: http://www.toronto2015.org/news-details/largest-everparapan-am-games-make-history/7621.

2. Toronto 2015 Pan Am / Parapan Am Games. About us [Internet]. Toronto (ON): Pan Am / Parapan Am Games; 2015 [cited $2016 \mathrm{Jul}$ 05]. Available from: http://www.toronto2015. org/more.

3. Barbeschi M, Endericks T. McCloskey, Vincent E, Llamas A, Berns S, Isla N, Nunn M, editors. Public health for mass gatherings: key considerations. Geneva $(\mathrm{CH})$ : World Health Organization; 2015 [cited 2016 Aug 25]. Available from: http://www.who.int/ihr/publications/WHO_HSE_GCR_2015.5/ en/.

4. Enock KE, Jacobs J. The Olympic and Paralympic Games 2012: literature review of the logistical planning and operational challenges for public health. Public Health 2008 Nov;122(11):1229-38. DOI: http://dx.doi.org/10.1016/j. puhe.2008.04.016. PubMed (https://www.ncbi.nlm.nih. 
gov/entrez/query.fcgi?cmd=Retrieve\&db=PubMed\&lis t_uids $=18619630 \&$ dopt $=$ Abstract $>$ ).

5. Elliot AJ, Hughes HE, Hughes TC, Locker TE, Shannon T, Heyworth $\mathrm{J}$ et al. Establishing an emergency department syndromic surveillance system to support the London 2012 Olympic and Paralympic Games. Emerg Med J 2012 Dec;29(12):954-60. DOI: http://dx.doi.org/10.1136/ emermed-2011-200684. PubMed (https://www.ncbi.nlm. nih.gov/entrez/query.fcgi?cmd=Retrieve $\& \mathrm{db}=$ PubMed\&li st_uids $=22366039 \&$ dopt $=$ Abstract).

6. Abubakar I, Gautret P, Brunette GW, Blumberg L, Johnson $D$, Poumerol $G$ et al. Global perspectives for prevention of infectious diseases associated with mass gatherings. Lancet Infect Dis 2012 Jan;12(1):66-74. DOI: http://dx. doi. org/10.1016/S1473-3099(11)70246-8. PubMed (https://www. ncbi.nlm.nih.gov/entrez/query.fcgi?cmd=Retrieve\&db=PubM ed\&list_uids=22192131\&dopt=Abstract).

7. McCloskey B, Endericks T, Catchpole M, Zambon M, McLauchlin J, Shetty N et al. London 2012 Olympic and Paralympic Games: public health surveillance and epidemiology. Lancet 2014 Jun;383(9934):2083-9. DOI: http://dx.doi.org/10.1016/S0140-6736(13)62342-9. PubMed (https://www.ncbi.nlm.nih.gov/entrez/query.fcgi?cmd=Retriev $\mathrm{e} \& \mathrm{db}=$ PubMed\&list_uids=24857700\&dopt=Abstract).

8. Elliot AJ, Morbey RA, Hughes HE, Harcourt SE, Smith S, Loveridge $P$ et al. Syndromic surveillance - a public health legacy of the London 2012 Olympic and Paralympic Games. Public Health 2013 Aug;127(8):777-81. DOI: http://dx.doi. org/10.1016/j.puhe.2013.05.007. PubMed (https://www.ncbi. $\mathrm{nlm}$.nih.gov/entrez/query.fcgi?cmd=Retrieve\&db=PubMed\&l ist_uids=23870845\&dopt=Abstract).

9. Kaiser R, Coulombier D. Epidemic intelligence during mass gatherings [Internet]. Euro Surveill 2006 Dec;11(12):E061221.3. Available from: http://www. eurosurveillance.org/ViewArticle.aspx?Articleld=3100 PubMed (https://www.ncbi.nlm.nih.gov/entrez/ query.fcgi? cmd=Retrieve\&db=PubMed\&list_ uids=17213571\&dopt=Abstract).

10. Thackway S, Churches T, Fizzell J, Muscatello D, Armstrong P. Should cities hosting mass gatherings invest in public health surveillance and planning? Reflections from a decade of mass gatherings in Sydney, Australia. BMC Public Health 2009 Sep;9:324. DOI: http://dx.doi.org/10.1186/14712458-9-324. PubMed (https://www.ncbi.nlm.nih.gov/ entrez/query.fcgi?cmd=Retrieve\&db=PubMed\&list_ uids=19735577\&dopt=Abstract).

11. Dapeng J, Ljungqvist A, Troedsson $H$, editors. The health legacy of the 2008 Beijing Olympic Games: successes and recommendations [Internet]. Geneva $(\mathrm{CH})$ : World Health Organization; 2008 [cited 2016 Aug 25). Available from: https://stillmed.olympic.org/Documents/Commissions_ PDFfiles/Medical_commission/The_Health_Legacy_of_ the_2008_Beijing_Olympic_Games.pdf.

12. Jones J, Lawrence J, Payne Hallström L, Mantero J, Kirkbride $\mathrm{H}$, Walsh $\mathrm{A}$ et al.; international team. International infectious disease surveillance during the London Olympic and Paralympic Games 2012: process and outcomes. Euro Surveill 2013 Aug;18(32):20554. DOI: http://dx.doi. org/10.2807/1560-7917.ES2013.18.32.20554. PubMed (https:// www.ncbi.nlm.nih.gov/entrez/query.fcgi?cmd $=$ Retrieve \&db $=P$ ubMed\&list_uids=23968829\&dopt=Abstract).

13. Jorm LR, Thackway SV, Churches TR, Hills MW. Watching the Games: public health surveillance for the Sydney 2000 Olympic Games. J Epidemiol Community Health 2003 Feb;57(2):102-8. DOI: http://dx.doi.org/10.1136/ jech.57.2.102. PubMed (https://www.ncbi.nlm.nih.gov/ entrez/query.fcgi?cmd=Retrieve\&db=PubMed\&list_ uids=12540684\&dopt=Abstract).

14. Tsouros AD, Efstathiou PA, editors. Mass gatherings and public health: the experience of the Athens 2004 Olympic Games [Internet]. Copenhagen (DE): WHO Regional Office for Europe; 2007 [cited 2016 Aug 25]. Available from: http:// www.euro.who.int/_data/assets/pdf_file/0009/98415/E90712. pdf.

15. KFLA Public Health Informatics. Acute Care Enhanced Surveillance [Internet]. Kingston (ON): KFL\&A Public Health Informatics; 2016 [cited 2016 May 30. Available from: http:// www.kflaphi.ca/acute-care-enhanced-surveillance/.

16. KFLA Public Health Informatics. PHIMS [Internet]. Kingston (ON) KFL\&A Public Health Informatics; 2016 [cited 2016 May 30. Available from: http://www.kflaphi.ca/phims/.

17. Dion M, AbdelMalik P, Mawudeku A. Big data and the Global Public Health Intelligence Network (GPHIN). Can Commun Dis Rep [Internet]. 2015 41(9):209-214. Available from: http:// www.phac-aspc.gc.ca/publicat/ccdr-rmtc/15vol41/dr-rm41-09/ ar-02-eng.php.

18. Stevenson V, Sachgau O, Bascaramurty D. Were the Pan Am Games worth it? And is Toronto Olympic-ready? Globe and Mail (Toronto Ed.) 2015 Aug 25 [updated 2015 Aug 29; cited 2016 Aug 25]. Available from: http://www.theglobeandmail. $\mathrm{com} /$ news/toronto/were-the-pan-am-games-worth-it-and-istoronto-olympic-ready/article26090427/.

19. Triple S, Triple S; Triple S Project. Assessment of syndromic surveillance in Europe. Lancet 2011 Nov;378(9806):1833-4. DOI: http://dx.doi.org/10.1016/ S0140-6736(11)60834-9 PubMed (https://www.ncbi.nlm. nih.gov/entrez/query.fcgi?cmd=Retrieve \&db=PubMed\&li st_uids=22118433\&dopt=Abstract)

20. Hadjichristodoulou C, Mouchtouri V, Vaitsi V, Kapoula C, Vousoureli A, Kalivitis I et al. Management of environmental health issues for the 2004 Athens Olympic Games: is enhanced integrated environmental health surveillance needed in every day routine operation? BMC Public Health 2006 Dec;6:306. DOl: http://dx.doi.org/10.1186/14712458-6-306. PubMed (https://www.ncbi.nlm.nih.gov/ entrez/query.fcgi?cmd=Retrieve\&db=PubMed\&list_ uids=17176469\&dopt=Abstract). 


\section{Appendix 1: Summary of three investigations conducted during the 2015 Pan/ Parapan American Games in Toronto, Canada}

On July 8 , an athlete presented to a Games medical clinic with suspected varicella (chickenpox) and was advised to self-isolate. The Public Health Coordinator notified the local public health unit by phone. Local and provincial public health developed guidance on addressing varicella in a Games environment where susceptibility may be higher than normal. When the diagnosis was confirmed by the public health laboratory, return-toplay guidance was provided to the athlete and coach, and a vaccination clinic was held for susceptible teammates. Secondary cases were expected to present between 15 July and 1 August; none were reported.

On July 17, the TO2015 medical team identified a possible cluster of gastrointestinal illness among accredited individuals, following an increase in requests for antidiarrheal medications from the Games pharmacy by a specific team. As per the established after-hours process, the TO2015 medical team informed the Public Health Coordinator, who notified a public health unit and the Ministry Emergency Operations Centre by phone. During the investigation, it was difficult to identify and follow-up with the affected individuals because of initial miscommunication at the lodging site and the transient nature of the population; several individuals left the Games soon after the investigation began. No common food exposure was identified among cases and no specimens were submitted to the laboratory; symptoms resolved within 24 hours of onset.

On July 30, a public health unit notified surveillance partners about two cases of campylobacteriosis through the teleconference and report. The two individuals had consumed food purchased while attending different Games events on separate dates. Further investigation determined that one case was unrelated to the Games. The food vendor related to the second case was inspected; food samples test results were negative.

\section{Issue Highlight:
Enteric Disease Outbreaks}

- Unique aspects of food and waterborne outbreaks in Canadian Indigenous peoples

- Cultural considerations in a Salmonella Reading outbreak investigation

- Plus additional peer-reviewed articles.

READ THE ISSUE: Web Search

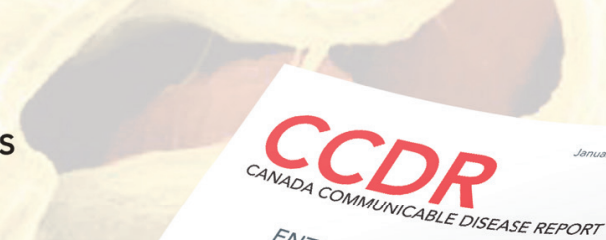

ENTERIC DISEASE OUTBREAKS

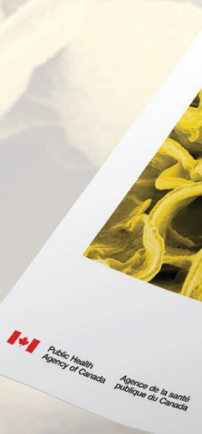

4 Previow

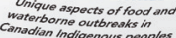
Ourbereak Report Sultural cons idorations ina Piopic Com

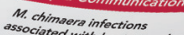
associated with hections
units: Who to test?

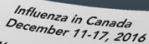
West Nilo virus in Canada 2016 Cansadäá 